\title{
OUTRAS HEGEMONIAS EM PESQUISAS SOBRE CURRÍCULOS TRANSNACIONAIS
}

\author{
OTHER HEGEMONIES IN RESEARCHS \\ ON TRANSNATIONAL CURRICULA \\ OTRAS HEGEMONÍAS EN LA INVESTIGACIÓN \\ DE CURRÍCULOS TRANSNACIONALES
}

\author{
MARIA DA GraÇA MoreIRA DA SILVA ${ }^{\mathrm{I}}$ \\ FERNANDO JosÉ DE AlmeIDA ${ }^{\mathrm{I}}$ \\ LuCILA RupP ${ }^{\mathrm{I}}$ \\ I Pontifícia Universidade Católica de São Paulo \\ (PUC/SP), São Paulo/SP - Brasil
}

RESUmo Este artigo destaca concepções curriculares contra-hegemônicas aos modelos imperantes e aponta possíveis epistemologias que se contrapõem às matrizes do neoliberalismo. A pergunta central pode, assim, ser resumida: O que é ser contra-hegemônico, ou o que é o "outro" frente às epistemologias neoliberais, os valores da globalização financeira, a ética da produtividade e do consumo sem fim? Desta pergunta, surgem outras. Para respondê-las, o trajeto pelos currículos de quatro países do Mercosul - Paraguai, Uruguai, Argentina e Venezuela -, evidencia formas diferenciadas para que os estudantes possam conhecer, analisar as múltiplas culturas, diagnosticar a realidade dos territórios em que vivem para participar melhor deles. Os currículos investigados apontam, explicitamente, a intencionalidade na construção de uma identidade sul-americana, que apresenta uma combinação entre temáticas universais e abordagem regionalista. Analisa-se aqui o documento-proposta feito em reunião plenária do Conselho Nacional de Educação (CNE), que apresenta os fundamentos para a construção de uma base curricular transnacional para constituir os currículos para a educação pública dos países do Mercosul, buscando uma nova hegemonia para países de culturas, economias e territórios diferentes, mas aproximados pela colonização ibérica e pelos destinos políticos comuns da história recente.

Palavras-chave: Currículo; Epistemologia; Política Educacional.

ABSTRACr This article highlights counter-hegemonic curricular conceptions to prevailing models and points out possible epistemologies that are opposed to the matrices of neoliberalism. The central question can thus be summarized: What does it mean to be counter-he- 
gemonic, or what is the "other" in the face of neoliberal epistemologies, the values of financial globalization, the ethics of productivity and endless consumption? From this question, others arise. To answer them, the route through the curricula of four Mercosur countries - Paraguay, Uruguay, Argentina and Venezuela - shows different ways for students to get to know, analyze the multiple cultures, diagnose the reality of the territories in which they live to better take part in them. The investigated curricula explicitly point to the intentionality in building a South American identity, which presents a combination of universal themes and a regionalist approach. Here are analyzed the propositions made at a plenary meeting of the National Education Council (CNE, in Portuguese), which presents the foundations for the construction of a transnational curriculum base to constitute the curricula for public education in Mercosur countries, to seek a new hegemony to countries of different cultures, economies and territories, but brought together by Iberian colonization and the common political destinies of recent history.

Keywords: Curriculum; Educational Policy; Epistemology.

RESUMEN Este artículo destaca las concepciones curriculares contrahegemónicas a los modelos imperantes y señala posibles epistemologías que se oponen a las matrices del neoliberalismo. La pregunta central se puede resumir así: ¿qué significa ser contrahegemónico, o qué es el "otro" frente a las epistemologías neoliberales, los valores de la globalización financiera, la ética de la productividad y el consumo sin fin? De esta pregunta surgen otras. Para responderlas, un recorrido por los currículos de cuatro países del Mercosur - Paraguay, Uruguay, Argentina y Venezuela - nos muestra diferentes formas para que los estudiantes puedan conocer, analizar las múltiples culturas, diagnosticar la realidad de los territorios en los que viven y participar mejor en ellos. Los currículos investigados apuntan explícitamente la intencionalidad de construir una identidad sudamericana, que presenta una combinación de temas universales y un enfoque regionalista. Aquí se analiza el documento propuesta elaborado en sesión plenaria del Consejo Nacional de Educación (CNE), que presenta las bases para la construcción de una base curricular transnacional que constituya los currículos de la educación pública en los países del Mercosur, buscando una nueva hegemonía a países de culturas, economías y territorios diferentes, pero unidos por la colonización ibérica y por los destinos políticos comunes de la historia reciente.

Palabras clave: Currículo; Epistemología; Políticas Educativas.

\section{APRESENTAÇÃO: PROPOSTAS CURRICULARES CONTRA-HEGEMÔNICAS EM PAÍ́SES DO MERCOSUL}

O presente artigo busca destacar dentro do cenário atual de pesquisas sobre currículo nos países do Mercosul (1995-2017) concepções curriculares que apresentem tendências contra-hegemônicas. O conceito de hegemonia, tratado em item específico, segue a definição de Gramsci (1968) e, a partir daí, dirige seu olhar para os modelos curriculares orientados pelos padrões da Organização para a Cooperação e Desenvolvimento Econômico (OCDE). 
A partir dos anos 1990, a busca pela integração dos países da OCDE trouxe, entre outras ações, novas orientações para os sistemas nacionais de educação e os currículos escolares. O conceito de currículo por competência passou a ser compreendido como "um novo paradigma normativo para as políticas educacionais a serem desenvolvidas nos países-membros da OCDE" (CHIZZOTTI; CASALI, 2012, p. 15-16). Tal conceito extrapolou as fronteiras do bloco e passou a pautar reformas curriculares em todo o mundo.

No Brasil, o conceito de competências e os preceitos curriculares importados da OCDE acabaram por orientar, em grande medida, o processo de elaboração de currículos nacionais e, também, a Base Nacional Comum Curricular (BNCC), prevista na Lei de Diretrizes e Bases da Educação Nacional (LDB), desde 1996.

O modelo de conhecimento, de sucesso e até de felicidade inculcado hegemonicamente pela economia neoliberal é o do consumo e da competição, que tem como contraposição um modelo ideológico de cooperação, fruição e partilha. Um modelo forma o consumidor/ cliente e o outro forma o cidadão, focalizando de modo bipolar a questão. É esse o dilema da educação escolar contemporânea e da organização de seu currículo. A quem interessa cada um desses modelos e como cooptar a sociedade para tal organização de país, economia e cultura? Essa é a batalha surda que se estabelece não apenas no Brasil, mas nos países que buscam guardar sua autonomia identitária e histórica diante das pressões da globalização liberal. Submetem-se a tais pressões a visão mais humanista do currículo escolar e a visão pragmatista e concorrencial da função da escola. Formam para o mercado.

Tudo se abala e, aparentemente, se inova a partir da perspectiva da construção de um currículo adaptado a esta ou aquela economia: leis, decretos, investimentos, aquisições maciças de escolas, movimento das editoras, investimentos em cursos a distância, leis de financiamento da educação, ingresso do capital financeiro nos grupos educacionais com abertura de capital, formação de conglomerados internacionais, crescimento da importância das avaliações internacionais na construção de currículos, da formação inicial de professores etc. Tais padrões axiológicos se ramificam e se sedimentam por meio dos exames do Programa Internacional de Avaliação de Estudantes (PISA), iniciativa da OCDE, e de exames bienais, que ocorrem desde 2000, atingindo, atualmente, 70 países. As avaliações do PISA funcionam como Cavalo de Troia e instalam lentamente o modelo de estrutura curricular da OCDE, como analisado por Chizzotti e Casali (2012). Não é à toa que os países que atingem a pontuação maior a cada biênio já têm seu regime econômico definido pela diretrizes culturais e valorativas do modelo da globalização financeira, como a Finlândia (2000, 2003, 2006), Xangai (representando toda a China) $(2009,2012)$ e Singapura (2015) - Cidade-estado insular com PIB per/capita de U\$62.100,00.

$\mathrm{O}$ apelativo de mundialização tem seu foco na perspectiva financista e econômica do trato da educação. O conhecimento e a função da escola se tornam mercadoria e seu objetivo maior é prover o mercado de mão de obra qualificada, ou de produzir um pensamento alinhado com a produtividade. Por um lado, esta visão torna a escola formadora para o mercado de trabalho, vendo na formação humanística mero adorno do espírito ou complementação da cultura folclórica. Ou funciona como pressão sobre uma pretensa capacidade da escola de gerar competitividade para a concorrência internacional entre as economias produtivas. A competitividade é formada pelas competências, nova alma do conhecimento. 
Por outro lado, atribui ao indivíduo toda a responsabilidade por seu futuro, sua profissão e inserção social.

O Estado foge sub-repticiamente da questão de sua responsabilidade sobre as grandes questões da organização dos interesses públicos sob a alegação de que o empresariado é melhor gestor das coisas públicas. Os conceitos de ordem, como empreendedorismo, liderança, protagonismo e itinerários formativos, ganham espaço. A busca de hegemonia do modelo neoliberal de economia vem pautando os objetivos e métodos de ensino e de aprendizagem. Inúmeras pesquisas se realizam, muitas vezes chamadas de "pesquisa por evidências", e se reforçam como a única forma de trazer a melhoria à educação.

No contexto das duas décadas iniciais do século XXI, o neoliberalismo, em suas múltiplas modalidades, se alastra em todo o mundo: dos Estados Unidos às nações escandinavas, da China às ilhas de produção da África e do Oriente Médio. A América Latina não escapa de suas pressões totalizantes. Neste artigo, o neoliberalismo é considerado, portanto, como ideologia hegemônica. Não é a única existente como ideologia, mas aquela que se sobressai, impõe-se, cria laços e amplia sua eficácia e suas ideias. Como toda a hegemonia é histórica, ela pode ser alterada. A contra-hegemonia de um momento histórico pode tornar-se hegemônica em outro. A flexibilidade do conceito de hegemonia viabiliza a compreensão de muitos dos movimentos da história.

É sobre a explicitação deste outros espaços contra-hegemônicos que se debruçarão nossas análises do cenário de currículos nacionais que constroem hegemonias. Os parâmetros dados aos currículos brasileiros do século XX não tinham o caráter nacional até a publicação da BNCC, em 2018. O trabalho de cotejamento de suas similaridades ou de complementaridade com os das outras nações não pôde ser feito, por isso, resumimo-nos aqui a destacar o que quatro países do Mercosul já vinham buscando como compreensão e construção de uma identidade de culturas, economias, conhecimentos, ciências e literaturas latino-americanas.

Neste artigo, destacam-se, nos currículos da Argentina, Paraguai, Uruguai e Venezuela, elementos epistemológicos que apontam para a contraposição dos preceitos da agenda hegemônica neoliberal que se implantam gradualmente em nossas sociedades. Por agenda neoliberal - pós 2008 - entende-se, neste artigo, a ideologia da organização política, financeira, cultural e tecnológica da sociedade que evita e desmobiliza a formação de blocos de países em defesa de interesses de alguns de seus valores culturais e econômicos. As desmobilizações dos blocos europeus, asiáticos e africanos, dos países Brasil, Índia e China (BRIC), do movimento contra as ações conjugadas como as da ONU, entre outros, evidenciam a tendência de baixa.

Para acessar o tema de forma concisa, dois conceitos esclarecedores serão os referenciais para nossa análise e explicitação das questões curriculares estudadas: epistemologia e hegemonia. Os conceitos serão tratados resumidamente, atendendo à necessidade de concisão própria de um artigo.

\section{EPISTEMOLOGIA}

Os currículos de qualquer programa educativo, em qualquer área da atividade humana, são marcados por uma dimensão epistemológica. Tenham ou não consciência dela os seus autores ou suas instituições. 
A epistemologia tem sua origem no conceito e na busca da verdade. Episteme é palavra grega que designa "ciência, saber, conhecimento". E a palavra epistemon designa "aquele que é competente em...", ou como verbo pode ser: tomar cuidado ou refletir (GEORGIN, s/d. p. 331).

Ela foi se constituindo na história da Filosofia como aquela área que cuida de determinar a origem lógica do pensamento, de sua coerência interna, do seu valor e de sua contribuição objetiva à busca ou construção da verdade. Verdade pode ser entendida como a adequação entre o pensamento e aquilo que ele representa (MORANDINI, 1963). Também chamada de crítica, desde a Idade Média, a epistemologia cuida do que é o entendimento da verdade (sua lógica, coerência e valor) em cada área do conhecimento. Valorizar a epistemologia significa partir do princípio de que é legítimo sempre buscar a verdade que subjaz na evolução das ciências e do conhecimento humano em geral. Essa busca contínua da verdade e de seus campos, chamada crítica, é a tarefa da epistemologia.

Ora, a construção de um currículo, percurso cognitivo pelo qual o ser humano experimenta o conhecimento e o organiza, passa necessariamente pela busca da verdade e de sua comprovação. Em se tratando, por exemplo, de uma área da ciência, como a Biologia, a Matemática ou a Geografia, o mais relevante do trabalho é comprovar a origem lógica de seus procedimentos e suas finalidades, assim como de sua contribuição na construção da verdade - principalmente se entendemos a realidade como um processo mutante e sempre mais complexo.

Quando são montados os currículos, os seus planejadores, sejam eles indivíduos, sejam grupos e instituições, escolhem cuidadosamente e criam seus fundamentos a partir de um modelo epistemológico. Buscam explicar a realidade com lógicas, reflexões, valores e de habilidades que deem consistência e realização a tais valores.

Como as epistemologias são construídas no interior de uma história de tensões e interesses, frequentemente elas retratam um recorte do real. Não explicam tudo. Nem sempre dominam os fins de seus usos. Nem sempre controlam os resultados das decisões sobre suas pesquisas em suas áreas de conhecimento. Mas não param de buscar sua ampliação explicativa.

É função dos educadores, por isso mesmo, refletir e posicionar-se sobre as diretrizes das alternativas sociais e políticas subjacentes às epistemologias desenvolvidas nos currículos escolares. Afinal, elas nunca explicam a totalidade do real, embora se insinuem como explicadoras plenipotenciárias dos fenômenos humanos, daí a importância do senso crítico sobre elas.

É sobre a análise das tendências epistemológicas nas propostas curriculares oficiais dos países do Mercosul que nosso artigo se debruça. A BNCC do Brasil não será objeto de análise, em detalhes, como foi feito com os currículos dos quatro outros países.

$\mathrm{O}$ presente artigo é resultado da pesquisa feita sob encomenda do CNE/MEC, um ano antes da proclamação da BNCC. As análises aqui feitas foram apresentadas à Plenária do CNE. Elas deveriam evidenciar os trajetos epistemológico e conceitual já percorridos pelos quatro países, que poderiam iluminar o desenho de uma nova Base Curricular Transnacional. O título da publicação, apoiada pela Organização das Nações Unidas para a Educação, a Ciência e a Cultura (UNESCO), traz claro o espírito daquela demanda: "Subsídios à elaboração da BNCC", que tinha à época a abertura para espaços políticos para um currí- 
culo transfronteiriço. Imaginava-se, então, a possibilidade de se criar espaços em que as questões latino-americanas fossem objeto de políticas pedagógicas comuns ao Mercosul. No entanto, no texto final da BNCC, nenhuma abertura foi dada para as perspectivas encontradas por ocasião da demanda da presente pesquisa. Apenas um modelo hegemônico de visão curricular se fez mais ouvido.

\section{HEGEMONIA E CONTRA-HEGEMONIA: O MESMO E O OUTRO}

A hegemonia é a busca da consolidação do poder pelo consenso. Quando um governo (os partidos e seus dirigentes) obtém o consenso, tem apoio porque a maioria da população acredita que, de fato, as diretrizes gerais das suas políticas são as melhores e mais eficazes.

O processo de produção de consenso é complexo e é o grande apelo dos partidos políticos, de seus atores e de cada governo. Tal consenso é construído em várias instâncias: religiosa, cultural, moral, econômica e educacional. Não se constroem consensos sem a articulação entre esses inúmeros fatores culturais e éticos. O objetivo máximo de um governo ou de um Estado é não precisar da força para continuar no poder, mas conseguir um acordo geral e duradouro sobre sua forma de exercer o comando. A hegemonia é definida por Gramsci (1978, p. 2010) como:

[...] a supremacia de um grupo social se manifesta como 'domínio' e como 'direção intelectual e moral'. No movimento de construção da hegemonia, um "grupo social é dominante dos grupos adversários que tende a 'liquidar' ou a submeter inclusive com a força armada e é dirigente dos grupos afins e aliados.

Nas pesquisas, práticas e desenhos dos currículos brasileiros, a luta pela hegemonia do modelo a ser vigente vem sendo oscilante e com variáveis pouco notadas ${ }^{1}$. A insistência em focalizar toda a estrutura da BNCC em competências revela uma tendência mais focada naquilo que o indivíduo cria dentro de si do que de uma cultura para a colocação das questões da vida social, da organização dos valores da vida comunitária. No fundo, a ideologia que rege tal decisão curricular é que a sociedade é a soma dos conjuntos de indivíduos bem formados. Preceito absolutamente presente no interior do neoliberalismo que advoga pelo fim das estruturas do Estado que possam cercear a livre expressão e interesse de cada um.

Na dimensão macroeconômica, tais princípios da educação correspondem à defesa do estado mínimo e da máxima livre concorrência, para se construir uma economia e sociedade justas, embora não equitativas. A hegemonia pode ser entendida enquanto dominação política e direção cultural para o exercício do poder pela coerção e da formação de um consenso passivo. O conceito gramsciano demonstra a importância da ideologia nas relações de poder e reforça a necessidade de busca do consenso, principalmente para as populações trabalhadoras. Nota-se aqui que o sentido de populações trabalhadoras nos 20 primeiros anos do século XXI é muito diferente um século depois das análises de Gramsci. As ca-

1 Saviani, no livro Pedagogia Histórico Crítica, ao analisar as tendências da educação brasileira leva em conta o movimento dialético que as confronta como uma busca da hegemonia para se impor à sociedade como modelo. Assim, cada tendência busca derrotar ou diminuir, passo a passo, vitória a vitória, a relevância das demais tendências pedagógicas para se impor. 
racterísticas das classes trabalhadoras, frente ao desemprego tecnológico, ao esvaziamento da produção mecânica e fabril e diante dos fluxos migratórios, em nada se assemelham à situação das classes operárias do início do século XX.

A articulação entre econômico, político e ideológico, e suas contradições permite encaminhar a questão da educação dos grupos subalternos. Tal articulação tem as finalidades mais universais do que a educação para grupos hegemônicos que colocam seus objetivos como objetivos gerais de um projeto de educação para todo o país. Ter como modelo curricular os parâmetros finlandeses, ou dos países ultra desenvolvidos com muitas condições materiais e culturais, representa a exclusão dos grupos mais significativos e numerosos do Brasil como prioridade das construções curriculares. A base comum curricular ideal para um país como o Brasil e os países da América Latina seria aquela que contemplasse elementos de análise crítica e diagnósticos das estruturas socioeconômicas, assim como da instrumentação para delas participarem as grandes massas da população no sentido de amplas mudanças de crescimento das conquistas democráticas ou de partilha das riquezas produzidas.

Organizar um currículo dito inovador não significa apenas uma nova forma cognitiva de equipar os indivíduos para o protagonismo individualista, para os valores de competição em mercados ou para um falso empreendedorismo a favor de uma economia que não produz trabalhos estruturantes para a sociedade. A questão é: o que é ser educado para viver bem nesse país? A educação que tem como objetivo elaborar uma cultura popular emancipadora e criar as condições de formação de um pensamento autônomo necessário para o enfrentamento político das questões da vida.

Formas alternativas de educação nascidas dos movimentos sociais são essenciais para criar um novo projeto social e político. Para tanto, faz-se necessário romper com o modo de pensar próprio do senso comum e entender que, para criar uma nova história, é importante criar também novos costumes e uma nova linguagem (SCHLESENER, 2016).

Entende-se por linguagem não apenas a oralidade ou a escrita, mas todas as formas de expressão que resultam de um modo de ser e de viver na sociedade: imagem, música, poesia, teatro, cinema, literatura e arte em geral, ou seja, todas as manifestações simbólicas que se ampliam constantemente com as novas tecnologias de comunicação constituem linguagem. Uma nova linguagem pode se criar apenas no movimento de transformação da realidade econômica, social e política, mudança que implica a transformação do modo de pensar e de sentir. Esse estudo parte de uma pesquisa sobre os países do Mercosul, uma vez que "Bases Transnacionais Curriculares" para economia de países próximos foram a forma como também a Europa iniciou seu processo de formar o bloco econômico da União Europeia, ao fim do século XX. Simultaneamente aos estudos e acordos para a unificação da moeda dos países europeus (2001), estudou-se em Lisboa, em 1997, a unificação dos estudos superiores baseados em diversos "considerandos", entre eles "que a grande diversidade de sistemas de ensino existentes na região Europa reflete as suas diversidades culturais, sociais, políticas, filosóficas, religiosas e económicas e representa uma riqueza excepcional que convém salvaguardar" (DIÁRIO DA REPÚBLICA, 1997, p. 1318).

Implantou-se, então, o Tratado de Bolonha (1999), como inspiração para o traçado das estruturas curriculares que permitissem o trânsito de conhecimentos e de pessoas entre os países da Comunidade Europeia, buscando a hegemonia para o modelo econômico e político. 


\section{Metodologia}

Este artigo, para responder à questão elaborada sobre as epistemologias contra-hegemônicas, analisa os documentos curriculares de quatro países do Mercosul. Lança mão da combinação de análise documental dos referenciais curriculares dos países do Mercosul e estudos de produções científicas relacionadas ao tema em tela, em particular a pesquisa de Almeida (2018). Os dados levantados foram categorizados, sistematizados em um quadro e analisados. Apresenta-se, a seguir, o quadro para a análise do currículo argentino como forma de ilustrar o método, sendo que as dos demais países foram suprimidas para o bem da fluência e do limite do texto.

Em todos os países do Mercosul existem documentos curriculares que estabelecem parâmetros amplos, que servem como base para as unidades educacionais desenvolverem seus projetos pedagógicos, considerando as características, demandas e realidades locais. Buscam-se, por meio das análises conceituais, as possíveis categorias contra-hegemônicas às conceituações curriculares neoliberais. A análise se dá sobre os currículos prescritos, embora as nomenclaturas variem, bem como a organização e definição dos conteúdos, as áreas analisadas são prioritariamente as Ciências Sociais, como História, Geografia, Cidadania, Linguagens ou temas afins. Como a abrangência dos anos/séries analisados é grande para ser exaurida neste artigo, o presente estudo traça uma visão ampla, focando os destaques que correspondem à preocupação central deste trabalho.

\section{A Construção do outro no Mercosul}

A partir da década de 1990, os países do Mercosul se envolveram em profundas reformas educacionais motivadas, em especial, por movimentos de reconstrução de suas democracias e por movimentos decorrentes da reorganização econômica e social mundial.

Por um lado, essas reformas derivaram de interesses externos à escola, que tiveram como mote a melhoria do rendimento dos estudantes para aumentar a competitividade laboral frente ao mercado de trabalho globalizado. Outros motivadores, oriundos de fatores externos, se relacionam à modernização do ensino e ao desenvolvimento pautados e financiados pelo Banco Mundial, Banco Interamericano de Desenvolvimento (BID) e outros. É evidente que a estrutura de organização da educação na contemporaneidade se baseia na cultura, política e no sistema econômico mundial, e não apenas nas políticas expressas nos planos nacionais curriculares.

Por outro lado, outro conjunto de motivações volta-se ao fortalecimento da democracia, após os diversos países sul-americanos terem sido submetidos a regimes militares e/ou ditatoriais desde a década de 1960, como Brasil, Argentina, Paraguai e Uruguai, caracterizados por "[..] regimes de modernização-conservadora. Comprometidos com o desenvolvimento econômico, porém regressivos no plano político" (INEP, 2008, p. 41), esses regimes geraram, após sua superação, a necessidade de redemocratização, buscando assegurar os direitos e o acesso aos bens sociais, políticas compensatórias, a universalidade e a equidade da educação.

Embora tenham passado por momentos semelhantes de reformas educacionais, os países sul-americanos conservaram suas especificidades na organização sociopolítica, re- 
lações de poder entre os atores sociais envolvidos na política educacional, o que resultou em diferentes desenhos curriculares. Identificam-se, no entanto, as tensões entre as agendas internacionais e a busca de uma identidade nacional ou, como defende este artigo, também de uma identidade sul-americana. Hegemonicamente, prevalece o paradigma da modernidade eurocêntrica (e norte-americana) como um conhecimento que se autodefiniu como superior e universal, com a decorrente desclassificação dos, assim chamados, saberes do Sul, considerados como conhecimentos e culturas periféricas e desqualificadas. Contra tal visão, buscam-se outros saberes.

Abdala (2008) pontua seis eixos centrais das tendências que pautaram as reformas educacionais nos países sul-americanos: descentralização da gestão escolar; mudanças nos conteúdos curriculares, modificações na formação inicial dos professores; mudanças na organização escolar, aumento nos investimentos e implantação de programas compensatórios.

Após esse brevíssimo contexto, apresentamos os dados levantados, focando as temáticas identitárias da América do Sul, presentes em quatro dos países do Mercosul, exceto o Brasil.

\section{Argentina}

As considerações partem dos dados da proposta curricular elaborada pela Argentina: Núcleos de Aprendizaje Prioritarios (ARGENTINA, 2004).

A descentralização da gestão administrativa ocorrida na Argentina na década de 1990 foi uma forma de diminuir a atuação das instâncias superiores do poder público federal na gestão dos sistemas nacionais de educação em favor de entidades de caráter regional ou local, não estatais.

Em 1993, a Lei Federal de Educação trouxe mudanças na estrutura da educação do país, como a organização da educação geral básica e obrigatória por dez anos e sua organização nos quatro níveis. A nova organização demandou a redefinição dos conteúdos. Assim, em 1995 foram publicados os Contenidos Básicos Comunes (CBC) para o Ensino Fundamental, definindo conteúdos por ciclo e servindo como orientações para a elaboração do Desenho Curricular Provincial. Entretanto, devido às diversas forças que integraram a construção dos $\mathrm{CBC}$, o documento tomou forma mais disciplinarizada dos conteúdos e cientificista.

Em 2004, tiveram início os estudos sobre Os Núcleos de Aprendizaje Prioritarios (NAP), por acordo do Conselho Federal de Educação. Um dos principais objetivos dos NAP é fomentar a integração e coesão nacionais.

Em 2006, foi promulgada a Lei de Educação Nacional (LEN), que buscou reformar e atualizar alguns aspectos do sistema educacional argentino. Pela LEN, os entes governamentais têm a responsabilidade de prover uma educação integral, permanente e de qualidade para todos os cidadãos, garantindo a igualdade, gratuidade e equidade no exercício desse direito.

O Plano Estratégico Nacional (2016-2021) organiza uma agenda de trabalho conjunta com os governos provinciais, visando a uma política pública educacional que atenda as particularidades das províncias e das localidades. 
Os NAP são orientadores do trabalho pedagógico, definem o que se deve ensinar sequencialmente por ano. Apresentam uma combinação entre temáticas universais e abordagem regionalista, incorporando aprendizagens ligadas ao Mercosul e à América Latina. As questões regionais são tratadas nos NAP da área de Ciência Sociais do $4^{\circ}$ ao $9^{\circ}$ ano, e sistematizadas a seguir.

\section{Quadro 1 - Núcleos de Aprendizagem Prioritários}

\begin{tabular}{|c|c|c|}
\hline Ano & Ciências Sociais & Aprendizagens \\
\hline $4^{\circ}$ & $\begin{array}{l}\text { En relación con } \\
\text { las sociedades a } \\
\text { través del tiempo }\end{array}$ & $\begin{array}{l}\text { - El reconocimiento de las principales motivaciones que impulsaron a los eu- } \\
\text { ropeos, desde el siglo XV, a explorar y conquistar el continente americano y } \\
\text { del impacto de su acción sobre las formas de vida de las sociedades indigenas, } \\
\text { atendiendo especialmente a las particularidades regionales. }\end{array}$ \\
\hline \multirow[t]{2}{*}{$6^{\circ}$} & $\begin{array}{l}\text { En relación con } \\
\text { la organización } \\
\text { de los espacios } \\
\text { geográficos }\end{array}$ & $\begin{array}{l}\text { - El conocimiento del mapa político de América Latina y de los procesos de } \\
\text { integración regional, en especial el Mercosur, considerando distintos tipos de } \\
\text { relaciones con el resto del mundo. } \\
\text { - El conocimiento de las principales condiciones ambientales de la Argentina y } \\
\text { de América Latina y el establecimiento de relaciones entre los principales usos } \\
\text { y funciones de los recursos naturales con la producción de materias primas y } \\
\text { energía. } \\
\text { - La identificación y comparación de las múltiples causas y consecuencias de } \\
\text { los principales problemas ambientales de la Argentina y de América Latina } \\
\text { que afectan al territorio y a la población, atendiendo a las distintas escalas } \\
\text { geográficas implicadas. } \\
\text { - El análisis y la comparación de diferentes espacios rurales de la Argentina y } \\
\text { América Latina a través del tratamiento de distintos sistemas agrarios y tipos } \\
\text { de productores. } \\
\text { - El análisis y la comparación del espacio urbano argentino y latinoamericano } \\
\text { a través de la identificación de las principales funciones urbanas, las activi- } \\
\text { dades económicas y las condiciones de vida de la población de las ciudades } \\
\text { latinoamericanas. }\end{array}$ \\
\hline & $\begin{array}{l}\text { En relación con } \\
\text { las actividades } \\
\text { humanas y la } \\
\text { organización } \\
\text { social }\end{array}$ & $\begin{array}{l}\text { - El reconocimiento de los vínculos entre Estados nacionales en el marco de los } \\
\text { procesos de integración regional, en especial el Mercosur. } \\
\text { - El conocimiento de la Declaración Universal de los Derechos Humanos y el } \\
\text { análisis de su vigencia en la Argentina y en América Latina. } \\
\text { - La reflexión y la comparación entre diversas manifestaciones culturales en } \\
\text { las sociedades latinoamericanas, promoviendo el respeto y la valoración de la } \\
\text { diversidad. }\end{array}$ \\
\hline
\end{tabular}




\begin{tabular}{|c|c|c|}
\hline $8^{\circ}$ & $\begin{array}{l}\text { En relación con } \\
\text { la organización } \\
\text { de los espacios } \\
\text { geográficos }\end{array}$ & $\begin{array}{l}\text { - El análisis de los intentos de construcción de Estados nacionales en América } \\
\text { Latina durante la primera mitad del siglo XIX, teniendo en cuenta los diversos } \\
\text { intereses sociales y regionales en juego. } \\
\text { - El conocimiento del mapa político de América teniendo en cuenta las distin- } \\
\text { tas formas de organización política (estados nacionales, colonias y dependen- } \\
\text { cias), las principales áreas de conflicto y tensión y el papel de los organismos } \\
\text { interamericanos e internacionales de cooperación. } \\
\text { - El conocimiento de distintos ambientes del continente americano, la identifica- } \\
\text { ción de los principales recursos naturales y sus formas de aprovechamiento. } \\
\text { - La comprensión de los principales problemas ambientales en América, reco- } \\
\text { nociendo sus causas y consecuencias, las politicas ambientales más relevantes y } \\
\text { las distintas escalas geográficas implicadas. } \\
\text { - La comprensión de las caracteristicas más relevantes de la población ame- } \\
\text { ricana y la explicación de sus principales problemáticas, particularmente las } \\
\text { vinculadas con la distribución, estructura y dinámica de la población; las } \\
\text { migraciones y las condiciones de vida y de trabajo. } \\
\text { - El conocimiento de la diversidad cultural en América y la comprensión de los } \\
\text { principales procesos de diferenciación y homogeneización en los sistemas de } \\
\text { conocimientos y creencias, valores, prácticas y tradiciones, atendiendo a sus } \\
\text { manifestaciones en distintos países y regiones del continente. } \\
\text { - El conocimiento de los procesos productivos en espacios urbanos y rurales } \\
\text { americanos teniendo en cuenta los actores sociales implicados y sus intencio- } \\
\text { nalidades, así como el impacto diferencial de las tecnologías de producción, } \\
\text { información y comunicación en las formas de organización territorial. } \\
\text { - La comprensión de las distintas formas de inserción de los países americanos } \\
\text { ellos, atendiendo especialmente a los flujos de circulación de bienes, servicios e } \\
\text { información en el contexto de la globalización y de los procesos de integración } \\
\text { regional. }\end{array}$ \\
\hline
\end{tabular}

Fonte: Organizado e grifado pelos autores.

A pesquisa de Almeida (2018) pontua os temas principais que emergem da análise dos NAP: passado colonial; conquista europeia e seus impactos nas populações indígenas; o Mercosul, a integração regional e a inserção econômica; recursos naturais e produção de matérias-primas; problemas ambientais; mapa político da região; espaço urbano versus espaço rural; condições vulneráveis de vida nas cidades; manifestações culturais e diversidade; direitos humanos; conflitos territoriais; características demográficas e migração.

No $4^{\circ}$ ano da educação primária, os estudantes têm contato com os motivos econômicos e políticos que impulsionaram os europeus a conquistar e explorar o continente americano e o impacto nas sociedades indígenas, o que indica o reconhecimento das sociedades e de suas culturas anteriores às conquistas europeias. Pode-se entender que 
a noção de "descobrimento" não tem lugar no currículo argentino, pois esse conceito implica uma ideia colonialista, como se nada ou ninguém existisse antes da chegada dos europeus à América.

É no $6^{\circ}$ ano que os temas relacionados à América do Sul e América Latina são adensados, articulando o conhecimento dos espaços geográficos com a atividade humana e relações sociais concretas e não idilicamente colocadas como cenário. Cabe ressaltar que já nessa série da escolaridade são tratados o Mercosul e suas relações com as demais nações do mundo, buscando conhecer as características do meio ambiente e o processo produtivo da matéria-prima e energia, bem como os problemas ambientais decorrentes que afetam os interesses das populações sul-americanas. Nesse mesmo ano, os estudantes entram em contato com os diferentes sistemas produtivos dos espaços rurais e urbanos, as atividades econômicas e as condições de vida do povo.

No mesmo tom, os NAP abordam o reconhecimento e a valorização das manifestações culturais e dos vínculos entre as sociedades latino-americanas. Conhecer as identidades, reconhecendo a diversidade étnica e o pluralismo cultural da região, é fundamental para a construção da identidade latino-americana, que é multicultural e predominantemente mestiça. O estudo das crenças dos povos é, em realidade, parte constitutiva da cultura e da cidadania, para além de ser tratado reduzidamente como folclore, e vem a expressar como o sul-americano interpreta a realidade.

Cabe ao currículo do $8^{\circ}$ ano a análise da construção dos estados nacionais na América Latina, sua organização política, áreas de tensões e conflitos, bem como a origem dos problemas vinculados à distribuição geográfica, migrações e condições de vida e trabalho e à organização territorial e integração regional. Assim, longe de estabelecer os padrões com a cultura norte-americana ou europeia, esta abordagem contém o olhar privilegiado na cultura e história do continente antes mesmo da chegada dos europeus, equivocadamente havida como único marco da sua identidade.

O $9^{\circ}$ ano do ciclo da educação primária trata como a Argentina está inserida nas redes globais de movimentos de bens, serviços, capitais, pessoas e informação, prestando especial atenção ao seu papel no Mercosul.

Como se pode vislumbrar, a centralidade latino-americana e sul-americana na interpretação da história, cultura, fluxos de produção, organização territorial e da "vida mesma" traz ao currículo de Ciências Sociais a posição contra-hegemônica à visão eurocêntrica. Conhecer e reconhecer as diferenças culturais que caracterizam as sociedades latino-americanas fortalece a construção da identidade e a desejada integração.

\section{EPISTEMOLOGIA E CONTRA HEGEMONIA NOS NÚCLEOS DE APRENDIZAGEM PRIORITÁRIAS DA AR}

Os elementos conceituais do currículo argentino presentes nos NAP, acima destacados, apontam para uma tendência epistemológica bastante imantada nas ideias de que um conhecimento pode ser explicitado, debatido, trabalhado na direção de um saber sólido fundamentado em princípios das ciências vistos interdisciplinarmente. Ora, trata-se aqui de uma clara visão epistemológica que é diversa da que propugna o ideário neoliberal de que 
sejam tratados no currículo, prioritariamente, os temas emergentes de interesses parcelares de grupos sociais homogêneos e em forma de bolhas autorreferentes.

Tal epistemologia neoliberal abandona os grandes temas das ciências, da história e da literatura integráveis como forma de compreensão do mundo. A sua prioridade para o currículo é a de construir o local de ocupação dos jovens em possíveis postos de trabalho. Um exemplo da visão contra-hegemônica: os objetivos do $6^{\circ}$ ano dos NAP propõem os estudos dos recursos naturais dos territórios reais e articulados com outros da América Latina, fenômenos historicamente constituídos, cuja população pode viver com problemas gerados pela forma de produção agrícola ou industrial profundamente articuladas com as questões urbanas da Argentina e das demais cidades da América Latina. Tais conteúdos não se desagregam, antes se articulam com economia, cultura e perspectivas.

\section{URUGUAI}

As considerações apresentadas partem dos dados da proposta curricular elaborada pelo Uruguai. Intitulado Programa de Educación Inicial y Primaria, o principal documento curricular uruguaio para a Educação Infantil (3 a 5 anos) e Primária (6 a 12 anos) a analisa segundo a categoria aqui elaborada para o uso interpretativo, epistemologias contra-hegemônicas.

O documento focaliza sua proposta na listagem de conteúdo, e não em aprendizagens e competências que os estudantes precisam desenvolver. Está subentendido que os conteúdos escolhidos são capazes de desenvolver habilidades de pensamento e de compreensão da realidade, mas as habilidades e competências possivelmente daí oriundas não são explicitadas.

Os conteúdos propostos pelo documento Programa de Educación Inicial y Primaria ligados à temática latino-americana estão presentes em três disciplinas: História, Geografia e Construção da Cidadania; a maioria concentra-se nas duas primeiras, no $4^{\circ}, 5^{\circ}$ e $6^{\circ}$ anos. A escolha de um conteúdo latino-americano como elemento formador da aprendizagem também traz consigo uma visão do que significa o conhecimento e a busca da interpretação da realidade (epistemologia). Se a Construção da Cidadania se segue à História e à Geografia da América do Sul, pode-se inferir que a habilidade daí desenvolvida virá a ser aquilo que a BNCC $^{2}$ afirma sobre as Ciências Humanas e Sociais Aplicadas:

\footnotetext{
Nessa etapa como os estudantes e suas experiências como jovens cidadãos representam o foco do aprendizado, deve-se estimular uma leitura do mundo sustentada em uma visão crítica e contextualizada da realidade, no domínio conceitual e na elaboração e aplicação das interpretações sobre as relações, os processos e as múltiplas dimensões da existência humana (BRASIL, 2017, p. 472).
}

Pode-se depreender das duas abordagens que a abstração trazida pelas habilidades genéricas, independentes dos conteúdos, se contraponham de fato como outra epistemolo-

2 Embora o escopo deste artigo não seja a comparação ponto a ponto entre as diretrizes curriculares dos países, aqui se destacam alguns pontos de diferença ou de semelhança: fala-se na BNCC (2018) da formação de um senso crítico abstrato desconsiderando a economia, a história e as características das desigualdades do país e das regiões, resumindo tudo no fecho da frase como uma genérica "existência humana". 
gia retratada no currículo uruguaio, que aponta temáticas latino-americanas como a mestiçagem, os instrumentos regionais, as literaturas e narrativas do Mercosul como forma de compreender - concretamente a partir da História, da Geografia ou das lendas regionais a identidade latino-americana. No currículo uruguaio, a compreensão da história e da dinâmica regional da América Latina funciona também como instrumento para o entendimento aprofundado do próprio país.

Os conteúdos de História abrangem um longo período - das primeiras ocupações humanas do território, a partir dos anos 40.000 A.C., passando pela colonização europeia e seus impactos na cultura, economia e sociedade, pelas revoluções hispano-americanas, pela Crise de 1929, ditaduras militares e democracia, até a formação do Mercosul.

Ora, ao afirmar que a História da identidade da América começou há 40.000 anos, e que aquilo que temos hoje não foi iniciado com a vinda dos Ibéricos, parte-se de uma outra epistemologia, diferente daquela adotada pelos currículos brasileiros, como se antes da chegada de Cabral os tempos fossem a-históricos. Como se os europeus tivessem dado existência às terras, aos povos e às culturas daqui. É como se a ontologia do ser deste hemisfério fosse dada pelo olhar, pela invasão e pela cultura do outro lado dos oceanos. Pode-se inferir que, nos conteúdos de Geografia, o foco do currículo está nos recursos hídricos da região e nos temas ligados à diversidade étnica e cultural da América Latina, incluindo questões de fronteiras, migrações, discriminação e desigualdades. Tal olhar sobre as fronteiras, migrações e diversidade não se encontra pautado nas questões das avaliações internacionais (PISA), sendo, assim, um sinal da contra-hegemonia trazida pela diretriz curricular em tela.

O estudo das bacias hidrográficas da América e os usos sociais dos cursos fluviais da hidrovia Paraguai-Paraná-Uruguai, no $4^{\circ}$ ano, preparam o estudante para a interpretação, no ano seguinte, de problemas que caracterizam a América Latina, como a discriminação no acesso ao trabalho, o trabalho infantil e a desigualdade social, étnica e de gênero. Ainda no $5^{\circ}$ ano, as crianças têm acesso a outros modelos de organização social, exemplo de uma epistemologia contra-hegemônica que apresenta outros modelos sociais possíveis. O Mercosul também é tratado nesta etapa do ensino básico, como a possibilidade de integração regional frente ao mercado internacional e aos bloqueios econômicos vigentes.

A disciplina Construção da Cidadania, conteúdo totalmente relacionado à América Latina, refere-se às diferentes crenças dos povos e como se manifestam nelas a estratificação social e o lugar da autoridade.

Entre o $7^{\circ}$ e o $12^{\circ}$ anos o documento das diretrizes curriculares nacionais uruguaio é denominado La Reformulación. Em relação aos conteúdos prescritos pelo documento no Ciclo Básico, a temática ligada à região latino-americana aparece com grande força no $8^{\circ}$ ano, na disciplina de Geografia. Nesta, todas as três etapas de ensino se centram na "análise multiescalar da diversidade espacial americana e sua inserção global". O seu objetivo é que o aluno entenda os processos de construção dos territórios americanos por meio das dinâmicas geográficas e da análise das decisões políticas que afetam essas regiões. Além disso, o documento coloca como objetivo-chave dessa disciplina a valorização da diversidade sociocultural e natural na construção dos territórios americanos e na importância dos desafios que enfrentam. Alguns dos temas enfatizados são: recursos naturais; ocupação 
dos territórios; organização produtiva; desigualdade; território urbano e blocos econômicos (URUGUAI, 2013).

É importante notar que esse documento indica os conteúdos a serem ministrados e sugere os contextos para seu ensinamento, citando diferentes países latino-americanos que podem servir de estudos de caso (um exemplo é: nível de desenvolvimento humano e econômico e suas manifestações espaciais; contexto sugerido: segregação espacial e metropolização).

Destaca-se, ainda, que esse documento curricular do Ciclo Básico propõe o estudo de temas latino-americanos, por meio da análise de expressões artísticas da região, nas disciplinas de artes e história. Nesta última, outros temas que ganham importância são o passado colonial da região e o período da independência, assim como questões de estrutura política e integração econômica.

A etapa final, o Ensino Médio, organiza-se conforme a seguinte estrutura: o $1^{\circ}$ ano é formado por um núcleo de disciplinas comuns para todos os alunos, enquanto no $2^{\circ}$ e $3^{\circ}$ anos há um núcleo comum obrigatório e opções diversificadas que os estudantes devem escolher conforme seus interesses.

A maior parte dos conteúdos relacionados à América Latina se concentra no $2^{\circ}$ ano, na opção humanística, presente nas disciplinas geografia humana e economia, história e sociologia. Os temas centrais são: fluxos populacionais; território; integração no mercado mundial; neoliberalismo e teoria da dependência; cultura; conflitos armados; e mudanças nas estruturas sociais. Já no $3^{\circ}$ ano, o Mercosul e a economia agroexportadora voltam a ganhar destaque.

\section{EPistemologia E CONTRA HEgEMONia No PROGRAMA de EDUCAÇÃo INI- CIAL E PRIMÁRIA}

A partir da análise dessas três etapas de ensino, observa-se que, como no caso argentino, os temas latino-americanos são estudados, em grande parte, de maneira conectada à realidade. Assim, a compreensão da história e da dinâmica regional da América Latina funciona como instrumento para a compreensão aprofundada do próprio país, no contexto necessário ao seu entendimento. Não se omitem as perspectivas do mundo de trabalho da região ou na macrorregião, mas as situam no âmbito das dimensões reais da sociedade e da economia, e não apenas para algumas vagas competências exigidas pelo chamado século XXI - uma outra grande abstração na construção curricular. Tais competências do século XXI se constituem como uma espécie de avatar das concepções hegemônicas do currículo.

\section{Paraguai}

O currículo da educação paraguaia é orientado pelo Programa de Estudios, cuja última versão foi publicada pelo Ministério de Educação do país em 2014. O documento estabelece parâmetros para todos os níveis do Ensino Básico, da Educação Infantil ao Ensino Médio e técnico, determinando competências e capacidades, além de diretrizes para a avaliação dos alunos, orientações metodológicas e sugestões bibliográficas para os professores. 
De acordo com levantamento de Almeida (2018), a temática latino-americana está bastante presente no currículo paraguaio principalmente nas disciplinas de Artes, Ciências Sociais, História e Geografia. Em Ciências Sociais, que se divide em História e Geografia a partir do $6^{\circ}$ ano, a colonização de matrizes comuns e as questões regionais são recorrentes, apresentando-se como contexto necessário para a compreensão da história e do desenvolvimento do próprio país. O entendimento histórico de sua economia, cultura e educação atravessa o tempo todo a perspectiva da formação das novas gerações.

No $4^{\circ}$ ano, para tratar da unidade Tempo e Espaço, os temas passam pela investigação das características culturais dos principais grupos aborígenes que habitaram a bacia do Rio da Prata antes da chegada dos europeus e identificam as características físicas mais importantes do Paraguai e dos países que conformam a bacia do Rio da Prata, com foco também em seus recursos naturais e culturais.

Ao abordar questões culturais de grupos que habitaram a região antes da chegada dos europeus ao continente, o currículo paraguaio contribui com a busca da identidade do sujeito latino-americano. Cibotti (2016) defende que tal identidade deve ser compreendida a partir de um primeiro sujeito: o vencido, o traumatizado, que teve seu tempo encerrado de maneira inesperada e violenta. "Nunca antes, um vasto grupo de povos e culturas, habitantes de um imenso espaço ocupado, mas isolado, sofreu a condição terminal de ver desaparecer seu mundo inteiro" (CIBOTTI, 2016, p. 19). A autora chama a atenção para a redução dos povos em uma unidade, o que acabou por anular a identidade de milhares de grupos autóctones, reunidos em uma única denominação: a de índios.

No $5^{\circ}$ ano, destacam-se as transformações ocorridas com a chegada dos espanhóis ao continente americano e, especificamente, ao Rio da Prata. Se a ideia de identidade regional acompanha as propostas da disciplina, no $6^{\circ}$ ano isso se torna mais evidente, quando $o$ currículo aponta para a identificação de "los factores socioculturales que intervienen en la construcción de la identidad regional sudamericana" (MINISTERIO DE EDUCACION Y CULTURA, 2014).

É no currículo de Artes, no entanto, que a América Latina tem destaque ainda maior. Mais do que os currículos da Argentina e do Uruguai, o documento do Paraguai destaca a força da região em suas manifestações artísticas e valoriza a aprendizagem desse legado. No $5^{\circ}$ ano, a unidade Los Lenguajes Artisticos destaca a interpretação vocal e instrumental de obras populares nacionais e americanas, valorizando recursos corporais e vocais para o contato com mitos, contos e lendas da América. No mesmo ano, a unidade Obras y autores lista como conteúdos as características da música americana pré-colonial dos países com influência indígena, além de elementos da dança, do teatro e de diferentes expressões artísticas indígenas americanas no contexto pré-colonial.

As questões latino-americanas também têm evidência nos currículos de Artes do $8^{\circ}$ e $9^{\circ}$ anos do Ensino Fundamental e do $2^{\circ}$ e $3^{\circ}$ anos do Ensino Médio. Destacam-se no $8^{\circ}$ ano, a presença de temas marcadamente regionais: as características melódicas, rítmicas, harmônicas e expressivas de obras musicais americanas; a identificação dos instrumentos utilizados na música popular e folclórica da região; a descrição dos agrupamentos musicais típicos dos países americanos; a produção de peças musicais simples baseadas em histórias, lendas e mitos, de origem paraguaia ou americana; a investigação sobre compositores e 
intérpretes de músicas significativas do Mercosul; e a valorização das manifestações musicais nacionais e americanas como expressão de uma identidade cultural determinada.

Já no $3^{\circ}$ ano do Ensino Médio, o currículo de Artes valoriza expressões contemporâneas, como o teatro de vanguarda que se desenvolveu na América Latina (o Teatro do Oprimido, de Augusto Boal, está previsto) e o novo cinema latino-americano. Em dança, o currículo prevê a investigação do ressurgimento do folclore no Paraguai e na América Latina a partir dos anos 1960.

\section{EPistemologia E CONTRA Hegemonia PRESENTES No "PRograma DE ES- TUDIO" Do PARAGUAI}

Os temas-problemas propostos para o trabalho pedagógico e educacional captados na pesquisa (ALMEIDA, 2018) podem ser sintetizados em duas dimensões. De um lado, epistemologicamente, a proposta curricular traz a lógica da relevância da história como chave de compreensão do processo de formação do cotidiano, marcado pelas populações e culturas destruídas e desaparecidas e sem identidade. A literatura, a dança, as lendas, o Teatro do Oprimido constituem-se no currículo como a forma de compreensão de si e do entorno latino-americano. O aprendizado da história, das artes, das ciências sociais se vincula também àqueles dos povos aborígenes e do seu território da Bacia do Prata, confluência de origem, identidades e projetos.

Do lado de sua dimensão contra-hegemônica, pode-se afirmar, a partir da pesquisa (ALMEIDA, 2018), que as tendências curriculares ditadas pelos padrões hegemônicos defendem (CHIZZOTTI; CASALI, 2012) exatamente o contrário: o estímulo ao desenvolvimento das competências individuais como único critério de êxito profissional. Evidencia-se, continuam os autores, apenas a história das economias das artes da Europa ou do hemisfério Norte como formadora do espírito humano; acirra-se a valorização de resoluções unilaterais dos conflitos pela força armada - com relatos das grandes guerras como libertadoras; apresentam-se as tecnologias digitais como condições necessárias e suficientes para resolverem os conflitos econômicos, entre outras.

\section{VENEZUELA}

O Currículo Nacional Bolivariano, publicado em 2007, orienta o desenho curricular do sistema educativo da Venezuela, foi promulgado no auge do poder de Hugo Chaves, reeleito em 2006, marcado por propostas ideológicas de cunho bolivariano. O documento se apresenta como um projeto de envergadura, por “[...] ditar as bases históricas, pedagógicas, filosóficas, sociais, culturais, psicológicas, políticas, metodológicas, científicas e humanistas" (MINISTERIO DEL PODER POPULAR PARA LA EDUCACIÓN, 2007, p. 5) a partir das quais se implementa a formação das crianças, jovens e adultos. As orientações estabelecem a carga horária das diferentes disciplinas e das várias etapas do ensino básico, além dos conteúdos a serem ensinados nessas etapas. $\mathrm{O}$ documento se atém às áreas de aprendizagem, sem chegar ao detalhamento dos conteúdos das disciplinas.

As questões latino-americanas ocupam lugar central no currículo que tem a integração da região como um de seus horizontes. O documento estabelece que a concepção curricular 
está pautada em abordagens pedagógicas de venezuelanos e latino-americanos, como Luis Beltrán Prieto Figueroa, Belén Sanjuán e Paulo Freire. O documento interpreta o currículo e a educação como formadores de seres humanos sociais e integrais, concepção baseada nas ideias de "liberdade, justiça, igualdade, fraternidade, felicidade, unidade, originalidade e emancipação" (MINISTERIO DEL PODER POPULAR PARA LA EDUCACIÓN, 2007, p. 8) de pensadores que defendiam a integração latino-americana, como Simón Rodríguez e Simón Bolívar.

Destaca-se que a integração e a cooperação entre os povos da América Latina, do Caribe e do mundo se configuram como um dos oito objetivos estabelecidos pelo documento. Nesse sentido, o currículo venezuelano busca fortalecer a noção de uma identidade latino-americana, cuja elaboração está em constante movimento, conforme aponta a historiadora argentina Cibotti (2016, p. 16): "a América Latina emerge no vasto espaço das Américas como um subcontinente com uma realidade comum e uma mesma herança e identidade em construção permanente".

Já no $1^{\circ}$ ano, os alunos entram em contato com manifestações artísticas locais e regionais, especificamente da Venezuela, América Latina e Caribe. No $2^{\circ}$ ano, a área de Linguagem, Comunicação e Cultura apresenta diferentes manifestações artísticas tradicionais da cultura latino-americana e caribenha. No $3^{\circ}$ ano, a área de Ciências Sociais, Cidadania e Identidade propõe a identificação do espaço da América Latina e do Caribe. Em seguida, a mesma área sugere o estudo da relação da Venezuela com os países da América e dos convênios de cooperação Alba e Mercosul.

A integração latino-americana é também tema do $5^{\circ}$ ano, ainda na área de Ciências Sociais, Cidadania e Identidade, e é tratada em outras etapas e áreas do ensino. No $7^{\circ}$ ano, por exemplo, o tema é trabalhado em Linguagem, Comunicação e Cultura a partir do estudo dos meios de comunicação social, tratados como ferramentas latino-americanas. No $8^{\circ}$ ano, a mesma área aborda a leitura e a produção de diferentes gêneros textuais também a partir de contos, novelas, lendas e mitos venezuelanos, latino-americanos e do Caribe. As manifestações artísticas e literárias da América Latina são estudadas a partir do $7^{\circ}$ ano, com especial interesse nas obras, artistas e escritores da região.

A história da América Latina e os contextos do desenvolvimento da região são valorizados em todas as etapas do currículo. No $8^{\circ}$ ano as manifestações artísticas das culturas maia, asteca, inca e chibcha são analisadas a partir de suas contribuições técnicas e artísticas para a história da América Latina. O currículo propõe uma análise que vislumbra os contextos históricos locais frente aos contextos históricos universais. Nesse sentido, as pinturas rupestres presentes na América Latina são comparadas com a arte rupestre universal.

Conforme Almeida (2018, p. 95), o currículo da Venezuela aborda as temáticas mundiais envolvendo os países latino-americanos a partir de uma perspectiva muito mais regional do que os demais currículos analisados. "A Venezuela trata o estudo de questões latino-americanas mais como um fim em si mesmo".

Tais opções representam uma exemplos de propostas, ou indicadores para a construção de um currículo contra-hegemônico às políticas que se instauram no modelo ideológico do movimento de globalização e com o correspondente enfraquecimento dos Estados nacionais, efeito ditado pela financeirização consumista das relações entre as culturas e os países. 


\section{Algumas conclusões ho fim}

A busca da resposta para a questão central que instigou esse artigo: O que é ser contra-hegemônico, ou o que é o "outro" frente às epistemologias neoliberais foi assentada no diálogo entre os conceitos de epistemologia e hegemonia. Para tal, analisou, nos currículos de quatro países integrantes do Mercosul, Paraguai, Uruguai, Argentina e Venezuela, trechos dos documentos que ilustram concepções curriculares que podem ser entendidas com potencial contra-hegemônico aos modelos imperantes, e apontam possíveis epistemologias que se contraponham às matrizes do neoliberalismo.

A opção pelas análises dos currículos dos países do Mercosul não foi ocasional, mas buscou, deliberadamente, se afastar dos currículos considerados como referência, como os da Finlândia, Coréia do Sul, Canadá ou Austrália, que já, anunciadamente, estão alinhados com as ideias neoliberais, considerados como hegemônicos neste estudo. Buscou-se, igualmente, se afastar dos conceitos, metodologias ou modismos trazidos de outros países. Em geral, eles se mostram estranhos à realidade, à cultura e ignoram os saberes locais - os saberes do sul. Por vezes, tais processos miméticos são decorrentes do agenciamento ou de articulação política de instituições internacionais ou grupos interessados em pautar a educação brasileira.

A primazia conferida aos currículos analisados é decorrente do contexto de proximidade geográfica, de colonização ibérica e de trajetórias sociais, políticas e econômicas que guardam semelhanças com o contexto brasileiro e, também, da busca de uma identidade sul-americana. Não se trata de uma análise comparativa com o currículo do contexto brasileiro, nem especificamente com a BNCC, mas aponta caminhos para fornecer subsídios a construção de novos currículos.

Os documentos analisados, longe de esgotar o assunto, apontam claramente que os quatro países do Mercosul enfatizam saberes que propõem uma construção epistêmica embasada nas características de seus povos, em suas culturas, economias e histórias. Assim, o outro como contra-hegemonia está representado neste artigo nos trechos dos currículos dos quatro países selecionados pelos autores e considerados como exemplos ou indicadores que trazem a valorização da realidade local, a formação dos jovens para análises e diagnósticos econômicos não meramente financistas; apresentam uma pedagogia de autonomia para grupos sociais excluídos, entre outros.

Os principais achados apontados aqui revelam a importância das escolhas curriculares contra-hegemônicas ao modelo neoliberal - explícitas ou latentes - que permitam construir-se um processo de vida, de experiência de múltiplas identidades e de coesão social entre países.

\section{REFERÊNCIAS}

ABDALA, F. Enseñanza Básica. In: INEP. Estudo Analítico Comparativo do Sistema Educacional do Mercosul (2001-2005). Brasília: Ministério da Educação, 2008. p. 77-93.

ALMEIDA, F. J. Base Curricular Transnacional para os países do Mercosul: urgência e oportunidade histórica. In: SIQUEIRA, I. C. P. (Org.). Subsídios à elaboração da BNCC. 
Estudos sobre temas estratégicos da parceria CNE e UNESCO. São Paulo: Moderna, 2018. p. 79-144.

ARGENTINA. Núcleos de Aprendizajes Prioritarios. Primer Ciclo EGB/nível Primario. Buenos Aires: Ministerio de Educación, Ciencia y Tecnología, 2004.

BAUMANN, Z. Vida para o consumo. Rio de Janeiro: Zahar, 2008.

BRASIL. Base Nacional Comum Curricular. Brasília: MEC, 2017.

CHIZZOTTI, A.; CASALI, A. O paradigma curricular europeu das competências. Cadernos de História da Educação, v. 11, n. 1, jan./jun. 2012.

CIBOTTI, E. América Latina en la clase de História. Buenos Aires: Fondo de cultura económica, 2016.

DIÁRIO DA REPÚBLICA. N. 76, de 30/03/1997. Lisboa. Disponível em: https://dre.pt/. Acesso em: 10 jan. 2021.

GEORGIN, Charles. Dictionnaire Grec-Français. Paris: Hatier, s/d.

GRAMSCI, A. Os intelectuais e a organização da cultura. Rio de Janeiro: Civilização Brasileira, 1968.

INEP. Estudo Analítico Comparativo do Sistema Educacional do Mercosul (20012005). Brasília: Ministério da Educação, 2008.

MINISTERIO DE EDUCACION Y CULTURA. Programa de Estudios. Assunção, 2014.

MINISTERIO DEL PODER POPULAR PARA LA EDUCACIÓN. Currículo Nacional Bolivariano. Caracas, 2007.

MORANDINI, F. Crítica. 5. ed. Roma: Aedes Universitatis Gregoriana, 1963.

SAVIANI, Dermeval. Pedagogia Histórico-crítica. 11.ed. Campinas, São Paulo: Editores Associados, 2012.

SCHLESENER, A. H. O Caderno A de Antônio Gramsci: a hegemonia, a linguagem, a literatura e seus desdobramentos na educação. Curitiba: Universidade Tuiuti do Paraná, 2016.

URUGUAI. Programa de Educación Inicial y Primaria. 3. ed. Montevideo: Administración Nacional de Educación Pública, 2013. 


\section{DADOS DOS AUTORES}

\section{Maria da Graça Moreira da Silva}

Doutora em Educação (Currículo) pela Pontifícia Universidade Católica de São Paulo. Docente do Programa de Pós-Graduação em Educação: currículo da Pontifícia Universidade Católica de São Paulo PUC/SP). mgraca.moreira@gmail.com

\section{Fernando José de Almeida}

Doutor em Filosofia da Educação pela Pontifícia Universidade Católica de São Paulo. Docente do Programa de Pós-Graduação em Educação: currículo da Pontifícia Universidade Católica de São Paulo PUC/SP). fjalmeida34@gmail.com

\section{LUCILA RUPP}

Doutoranda do Programa de Pós-Graduação em Educação: currículo da Pontifícia Universidade Católica de São Paulo PUC/SP). lucilalrupp@gmail.com

Submetido em: 06-12-2019

Aceito em: 27-02-2021 